\title{
УДК 338.2:339.9
}

https://doi.org/10.52058/2708-7530-2021-12(18)-338-344

Морозова Ольга Григорівна кандидат економічних наук, доцент, доцент кафедри економіки та фінансів, Херсонський державний аграрно-економічний університет, вул. Стрітенська, 23, Херсон, 73006, e-mail: postolgamorozova@gmail.com, https://orcid.org/0000-0002-6501-3561

\section{ПЛАНУВАННЯ ЯК ОСНОВА СТАЛОГО РОЗВИТКУ ПІДПРИСМСТВА В УМОВАХ ГЛОБАЛІЗАЩІЇ}

Анотація. У статті обгрунтовано необхідність впровадження дієвого процесу стратегічного планування з урахуванням основних положень концепції розвитку підприємства з метою підвищення ефективності його функціонування. Встановлено, що при впровадженні моделі стратегічного планування, у переважній більшості підприємств спрацьовують ринкові механізми саморегулювання. Досліджено що підіприємства, як не мають реального досвіду та напрацьованих інструментів переходу до нових умов діяльності на основі використання стратегічного планування не спроможні підвищити економічну ефективності діяльності в умовах глобалізації. Обгрунтовано, що економічна ефективність функціонування підприємств повинна вмістити трансформацію традиційної системи цілей і показників ефективності у результуючі показники, що характеризують вектор економічної, соціальної та екологічної ефективності. Виявлено, що даний підхід відповідає глобалізаційним тенденціям розвитку та стратегічним планам на сучасному етапі сталого розвитку підприємств. Охарактеризовано провідна роль стратегічного планування у забезпеченні розвитку підприємств та трансформацію механізмів для ефективного планування $\mathrm{i}$ реалізації його цілей. Доведено обов'язковість поступової імплементації стратегічного планування та переходу до ефективної діяльності через призму концепції сталого розвитку для підприємств України.

Ключові слова: стратегічне планування, сталий розвиток , економічна ефективність, глобалізація.

Morozova Olha Hryhorivna Candidate of Economic Sciences, Associate Professor of Economics and Finance, Kherson State Agrarian University, Street St., 23, Kherson, 73006, e-mail: postolgamorozova@gmail.com, https://orcid.org/0000-0002-6501-3561

\section{COMMERCIAL EDUCATIONAL INSTITUTIONS AS THE FIRST SPECIALIZED INSTITUTIONS OF ECONOMIC EDUCATIOH}

Abstract The article substantiates the need to implement a strategic planning workflow based on the main provisions of the concept of enterprise development in 
order to improve the efficiency of its functioning. It has been established that when a strategic planning model is introduced in the vast majority of enterprises, market selfregulation mechanisms are triggered. It is investigated that enterprises that do not have real experience and developed tools for transition to new conditions of activity based on the use of strategic planning are not able to increase the economic efficiency of activities in the context of globalization. It has been substantiated that the economic efficiency of the functioning of enterprises should contain the transformation of the traditional system of goals and performance indicators into indicators characterizing the vector of economic, social and environmental efficiency. It was revealed that this approach meets the globalization trends of development and strategic plans at the present stage of sustainable development of enterprises. The leading role of strategic planning in ensuring the development of enterprises and transformation of mechanisms for effective planning and implementation of its goals is characterized. The necessity of the gradual implementation of strategic planning and the transition to effective activity through the prism of the concept of sustainable development of Ukrainian enterprises has been proved.

Keywords: strategic planning, sustainable development, economic efficiency, globalization.

Постановка проблеми.Планування розвитку підприємства є стратегічною необхідністю як в умовах постійних змін, які відбуваються у зовнішньому глобальному середовищі, так і для стабільного функціонування підприємств . Більше того, потреба в плануванні стратегії розвитку будь-якого підприємства обумовлена, перш за все, прагненням необхідністю підвищення ефективності його діяльності. Успіх аграрної політики нашої держави багато в чому може визначатися мобілізацією внутрішніх ресурсів і можливостей кожним аграрним підприємством, умінням кожного керівника правильно вибрати стратегічний курс розвитку та здатністю управляти підприємницьким ризиком в досягненні намічених стратегічних цілей.

Актуальним завданням сталого, сучасного економічного розвитку України $\epsilon$ створення передумов ефективного i динамічного переходу до ринкових відносин в умовах глобалізації . Важливою $є$ модифікація надмірної концентрації і монополізації виробництва, удосконалювання організаційних та структурних відносин, перегляд застарілих командних економічних зв'язків i методів керування.

За цих умов особливої уваги набуває необхідність розвитку підприємницької активної позиції, діяльність підприємств і організацій, спрямованих на споживача, i остаточний результат - економічний ефект (прибуток).

Розв'язання проблем, пов'язаних 3 необхідністю забезпечення ефективної роботи підприємства, не тільки сьогодні, але й у перспективі, залежить від ступеня використання методології і методів стратегічного керування. 
Поняття "стратегія" в управлінні підприємством як соціально-економічною системою має на увазі довгостроковий план дій з керівництва підприємством а також відповідним колективом, спрямований на досягнення цілей організації.

Цей план переслідує чітко визначену мету i будується на реальних можливостях підприємства, з огляду на умови, у яких вона функціонує.

Стратегія планування підприємства $є$ базисом стратегії планування, за допомогою якого на підприємстві вирішується комплекс проблем, пов'язаних 3 цілеспрямованою орієнтацією випуску інноваційної продукції й асортименту, впровадженням і використанням нових технологій, удосконалення маркетингу, розвиток структури керування підприємством, своєчасною i якісною перепідготовкою кадрів.

Аналіз останніх досліджень та публікацій. Питаннями стратегічного планування діяльності підприємств висвітлили в своїх працях такі вітчизняні та зарубіжні вчені, як .О.М Алимов, І.А. Ігнатієва, . А.Л. Гапоненко, С. В. Оборська, М.С. Федоркін, А. Плануг, Р. Уайлд, Р. Хагн, М. Котч, H. Косіолі та інші. Не дивлячись на помітну зацікавленість процесом планування вітчизняними та зарубіжними вченими, однак його проблематиці наразі приділено ще не достатньо уваги.

Мета статті. Ціллю дослідження $є$ проведення всебічної оцінки різних трактувань поняття «стратегічне планування», уточнення його сутності та визначення взаємозв'язку з категорією «розвиток». Виходячи із поставлених цілей необхідно вирішити такі завдання: розкриття сутності стратегічного планування; теоретичне обгрунтування форм, видів, принципів та етапів планування; визначення взаємозв'язку стратегічного планування та розвитку підприємства.

Виклад основного матеріалу.В сучасному світі, через досить не стійкі фактори зовнішнього середовища, перед кожним підприємством гостро постає питання, щодо здійснення його сталого розвитку. Досить необхідною умовою нормального функціювання підприємств, як на ринках зовнішнього, так і на ринках внутрішнього середовища, $\epsilon$ бізнес-план, що є основною допомогою при формуванні стратегії подальшого розвитку підприємства та подолання проблем, що можуть з'явитися.

Планування $€$ досить необхідною частиною діяльності кожного підприємства, адже саме великий досвід організацій не тільки в Україні, але i по всьому світу, показав, що однією 3 причин зниження економічних показників є саме недооцінювання чи зменшення процесу планування [1].

Планування діяльності підприємства — це процес, за допомогою якого

здійснюється формування та визначення цілей підприємства, а також засобів та методів їх досягнення.

Рассел Лінкольн зауважив, що планування «це проект майбутнього i шляхів його досягнення». Економіст-теоретик, В. Медведєв, визначив «під плануванням функцію, що допомагає знайти дії, кінцевим результатом яких $\epsilon$ 
складений план» [2]. Бляхман запропонував визначення, що «планування - це одна $з$ основних, а саме чотирьох, функцій менеджменту. Крім цього потрібно також зауважити, що планування - це управління на підприємстві, яке охоплює комплекс робіт, аналіз ситуацій i впливу чинників зовнішнього середовища» [2].

Кожна організація, не зважаючи на вид діяльності та його масштаби

займається плануванням. Якщо ж на підприємстві буде відсутність планів, то безсумнівно буде втрачатися позиція на ринку, буде досить не стійкий фінансовий стан, а також, в окремих випадках, банкрутство, що виникає через несвоєчасні зміни орієнтації та помилковими маневрами.

Основними завданнями, які покладені на планування, потрібно віднести: оцінка стану економіки на підприємстві, його соціальних процесів, а також тенденцію діяльності; передбачення, в науковому напрямку, економічного стану підприємства, разом із тенденціями розвитку галузі; здійснення контролю щодо діяльності головних ресурсів, а саме технічних,матеріальних та трудових, а також їх своєчасну заміну [3].

Для того, щоб підприємство дійсно успішно працювало та отримувало в кінцевому результати позитивні показники своєї діяльності, воно повинне здійснювати довгострокове планування, на період декількох наступних років, а також більш деталізований план, в якому буде захоплений кожен підрозділ організації [4].

Довготермінове планування на підприємствах може складатися лише 3 мети, а саме, що є основним для підприємства, а також з головних напрямів діяльності, адже інформація про майбутнє організацій є досить мінімальна, а зміни на підприємстві навпаки, досить високі.

Календарні плани на місяць, квартал чи навіть на півріччя, вказують завдання, а також і цілі підприємств, крім цього до них входить інформація щодо замовлень, забезпечення ресурсами, ступінь завантаженості, що допоможе підприємству в подальшому покращити певні показники. В таких планах також можливо прорахувати витрати на зміну обладнання, покращення продукції, потужностей організації [5].

Також вивчаючи дану проблему, слід зазначити позитивні зміни, що досягаються через планування, а саме це можливість попередження проблем, що можуть виникнути, забезпечення сприятливих умов в майбутньому, стимулювання персоналу щодо реалізації рішень, поліпшення виконання дій управлінським персоналом.

Крім цього, від того, на скільки якісним буде планування, й залежить, на скільки підприємство буде швидко покращувати не тільки економічні показники, але й роботу в цілому. Тому слід виділити чотири основні принципи плануванням, які визначив Файоль. До цих принципів відносяться єдність, неперервність, гнучкість, точність та участь: 
- Принцип єдності, який також можна назвати принципом системності, можливо охарактеризувати тим, що планування має системний характер, тобто всі елементи в плануванні сукупні та взаємодіють між собою. Крім цього саме в принципі єдності все орієнтоване на загальну мету.

- Принципом неперервності слід вважати головним те, що «необхідна підтримка неперервності планової перспективи, а також взаємозв'язок між всіма типами планування: короткотермінового, середньотермінового та довготермінового» [7].

Саме цей принцип передбачає швидке коригування планів з розрахунком змін як у внутрішньому, так і у зовнішньому середовищі підприємства.

- Принцип гнучкості передбачає змогу зміни планів в процесі планування, згідно змін, що відбуваються не тільки у внутрішньому, але і у зовнішньому середовищах.

- Принцип точності означає, що під час складанні плану, зазначається все досить конкретно та чітко.

- Останнім принципом вважається «принцип участі, під яким йдеться на увазі, що кожний працівник підприємства стає учасником планування незважаючи на те, яка в нього посада та які функції він виконує»[6].

Якщо ж брати до уваги підприємства України, та їх особливості планування, то слід зазначити, що «починаючи з 2010 року, досить помітним $\epsilon$ значне зниження планування менеджменту на всіх його ступенях. Одним 3 основних чинників, що вплинули на це, $\epsilon$ несприятливе ставлення до директивного планування, яке, якщо брати його разом 3 адміністративною системою управління, понижує ініціативу організацій, а тому i певних працівників»[7].

Головними чинниками, що відрізняють Україну від інших країн у системі планування, $є$ те, що план на підприємствах не $є$ обов'язковою умовою його діяльності. Також різниця відчувається у досить низькій конкурентній позиції створених бізнес-планів, що виникає через неякісну розробку цих планів, в результаті недостатність інформації при його складанні.

Від початку отримання підприємствами економічної свободи, та разом 3 тим, впровадження закону "Про підприємства в Україні", зазначалось, що кожна організація має право самостійно планувати свою діяльність, а також окреслювати перспективи свого розвитку в подальшому плані.

Проте, слід зауважити, що кожному 3 підприємств слід також уміло користуватися цим законом та правами, що він надає. Адже згідно до законодавства, «з головних елементів економічної роботи, до якої входить контроль, облік, аналіз, та інші, основним для всіх підприємств є лише бухгалтерський облік»[3].

Наступним чинником, який також негативно вплинув на планування на кожному 3 підприємств України, є гіперінфляція, що спостерігалася в країні починаючи з 1993 року. Через звільнення цін та заробітної плати робітників від 
адміністративного контролю, досить швидко відчувся негативний ефект на якості та стану внутрішнього планування підприємств[7].

Також впливає й те, що зараз все більше увага економістів приділена економічному суверенітету, зміни форми власності, та інших макроекономічним проблемам. Крім цього досить важливою передумовою погіршення планування вважається й малий досвід, а іноді і зовсім його відсутність в плануванні в умовах ринку.

Якщо підсумувати все вище зазначене, можна погодитись 3 думкою професора Коваленка, який вважає, «що зараз все помітніше зникає планування всередині підприємств, а бухгалтерський облік більше приділяє увагу фінансовим аспектам, i тому все помітніше занепадає аналітична робота. Якщо всім цим чинникам не намагатися дати раду, то можливо передбачити розпад аналітичної та планової роботи, а також примітивізацію обліку і в кінці кінців все, що було здобуте раніше втратиться назавжди»[5].

Тому в результаті усього вищезазначеного, можна зробити висновок, що планування - це прогнозування цілей, що $є$ досить необхідними на всіх підприємствах та без якого неможливий сталий їх розвиток. Саме якісна розробка планування з розрахунком всіх моментів допомагає підприємствам.

Висновки. Можна констатувати що стратегія «не функція часу, а функція поставленої мети розвитку, специфічний, просторово орієнтований на майбутнє напрям розвитку»[5]. Воно базується, з одного боку, на цілях і завданнях, поставлених у ході розробки стратегії, а з іншого - на прогнозах у різних сферах розвитку. Необхідність впровадження дієвого процесу стратегічного планування 3 урахуванням основних положень концепції розвитку підприємства 3 метою підвищення ефективності його функціонування $\epsilon$ необхідною умовою. Впровадженні моделі стратегічного планування, забеспечують у переважній більшості підприємств ринкові механізми саморегулювання. Підіприємства, як не мають реального досвіду та напрацьованих інструментів переходу до нових умов діяльності на основі використання стратегічного планування не спроможні підвищити економічну ефективності діяльності в умовах глобалізації. Економічна ефективність функціонування підприємств повинна вмістити трансформацію традиційної системи цілей i показників ефективності у результуючі показники, що характеризують вектор економічної, соціальної та екологічної ефективності. Даний підхід відповідає глобалізаційним тенденціям розвитку та стратегічним планам на сучасному етапі сталого розвитку підприємств. Провідна роль стратегічного планування у забезпеченні розвитку підприємств та трансформацію механізмів для ефективного планування і реалізації його цілей. Обов'язковість поступової імплементації стратегічного планування та переходу до ефективної діяльності через призму концепції сталого розвитку для підприємств України. 


\section{Лimepamypa:}

1. Алимов O.M., Ігнатієва I.A. Балансування стратегій в стратегічному наборі підприємства// Актуальні проблеми економіки, № 7(49). - 2005. - 115 с.

2. Гапоненко А. Л. Стратегическое управление: Учебник - М.: Омега, 2004 - 466 с.

3. Дацій О. I. Планування і контроль діяльності підприємства: Навч. посіб./ Гуманітарний ун-т «Запорізький ін-т державного та муніципального управління». Запоріжжя, 2005 - 40 с.

4. Жаліло Я. Економічна стратегія як категорія сучасної економічної науки// Економіка України, № 1. - 2005. - 72 с.

5. Кахович Е.А., Кахович Ю.А. Стратегічне планування та управління в роботі юридичних служб суб'єктів господарювання / Е.А. Кахович, Ю.А. Кахович // Облікові записи Таврійського національного університету ім. В.І. Вернадського. Серія: Юридичні науки. 2014. - № 1. - 113 c.

6. Пасічник В. Г. Планування діяльності підприємства: Навч. посіб. / В. Г. Пасічник, О. В. Акіліна. - К.: Центр навчальної літератури, 2005 - 255 с.

7. Федоркін М.С. Резерви конкурентоспроможності підприємства / Холодний Г.О. // Вісник Хмельницького національного університету. Економічні науки. - 2007. - 119 с.

8. Холодний Г.О. Теоретичні аспекти стратегічного планування на підприємствах України: (підсумки 4-ї Міжнар. конф. «Харків-2011/ Холодний Г.О. // Вісник економіки. 2011. - 54 c.

\section{References:}

1. Alimov, O.M., Ignatieva, I.A. (2005). Balansuvannja strategij v strategichnomu nabori pidpriemstva [Balancing strategies in the strategic set of the enterprise]. Aktual'ni problemi ekonomiki - Actual problems of economy, 7(49), 115 [in Ukrainian].

2. Gaponenko, A. L. (2004). Strategicheskoe upravlenie [Strategic Management]. M.: Omega [in Russian]

3. Dacij, O. I. (2005). Planuvannja i kontrol' dijal'nosti pidpriemstva [Planning and control of the enterprise] .Zaporizhzhja: Gumanitarnij un-t «Zaporiz'kij in-t derzhavnogo ta municipal'nogo upravlinnja» [in Ukrainian].

4. Zhalilo, Ja. (2005). Ekonomichna strategija jak kategorija suchasnoï ekonomichnoï nauki [Economic strategy as a category of modern economic science]. Ekonomika Ukraïni - Economy of Ukraine, 1, 72 [in Ukrainian].

5. Kahovich, E.A., Kahovich, Ju.A. (2014). Strategichne planuvannja ta upravlinnja v roboti juridichnih sluzhb sub'ektiv gospodarjuvannja [Strategic planning and management in the work of legal services of business entities]. Oblikovi zapisi Tavrijs'kogo nacional'nogo universitetu im. V.I. Vernads'kogo. Serija: Juridichni nauki - Accounts Tavriya National University. VI Vernadsky. Series: Legal Sciences, 1, 113 [in Ukrainian].

6. Pasichnik, V. G. (2005). Planuvannja dijal'nosti pidpriemstva [Planning of the enterprise]. K.: Centr navchal'noï literaturi [in Ukrainian].

7. Fedorkin, M.S. (2007). Rezervi konkurentospromozhnosti pidpriєmstva [Reserves of enterprise competitiveness]. Visnik Hmel'nic'kogo nacional'nogo universitetu. Ekonomichni nauki Bulletin of Khmelnytsky National University. Economic sciences, 119 [in Ukrainian].

8. Holodnij, G.O. (2011). Teoretichni aspekti strategichnogo planuvannja na pidpriemstvah Ukraïni [Theoretical aspects of strategic planning at the enterprises of Ukraine]. Visnik ekonomiki Bulletin of Economics, 54 [in Ukrainian]. 